\title{
The Brazilian version of the SRS-22r questionnaire for idiopathic scoliosis
}

Paula M. F. Camarini, Giselle C. L. Rosanova, Bruna S. Gabriel, Priscila E. S. Gianini, Anamaria S. Oliveira

\begin{abstract}
Background: The SRS-22r questionnaire is a well-accepted instrument used to measure health-related quality of life in patients with idiopathic scoliosis. No validated tool exists in Brazil for idiopathic scoliosis, and the use of the SRS-22r in non-English Laguage contries requires its transcultural adaptation. Objective: The objective of this study was to culturally adapt the translated Brazilian version of the SRS-22r questionnaire and to determine its reliability using statistical tests for internal consistency and test-retest reliability. Method: The transcultural adaptation process was carried out according to the recommendations of the American Academy of Orthopedic Surgeons. The pre-final version was administered to 44 patients with idiopathic scoliosis. The mean age of the participants was 18.93 years and the mean curve magnitude was $54.6^{\circ}$. A subgroup of 30 volunteers completed the questionnaire a second time one week later to determine the scale's reproducibility. Internal consistency was determined using Cronbach's alpha coefficient, and the test-retest reliability was determined using the Intraclass Correlation Coefficient (ICC). Results: No floor effects were observed using the Brazilian version of the SRS-22r. Ceiling effects were observed in the Pain and Satisfaction with Management domains. The internal consistency values were very good for 3 domains and good for 2 domains. The ICC values were excellent for all domains. Conclusions: The high values of internal consistency and ICC reproducibility suggest that this version of the questionnaire can be used in Brazilian patients with idiopathic scoliosis.
\end{abstract}

Keywords: quality of life; scoliosis; questionnaires; rehabilitation.

\section{HOW TO CITE THIS ARTICLE}

Camarini PMF, Rosanova GCL, Gabriel BS, Gianini PES, Oliveira AS. The Brazilian version of the SRS-22r questionnaire for idiopathic scoliosis. Braz J Phys Ther. 2013 Sept-Oct; 17(5):494-505. http://dx.doi.org/10.1590/S1413-35552012005000108

\section{Introduction}

In the past few years, assessing Health-Related Quality of Life (HRQoL) based on a patient's perception of their condition and its treatment effects has raised interest among physicians and researchers ${ }^{1-3}$. Objective measures, although highly useful, are weakly related to patients' actual concerns, which include concerns about their symptoms and the functional, social and psychological aspects of their condition ${ }^{4-7}$. Hence, subjective measures can be an important complement to a traditional clinical evaluation $^{7,8}$, and as a result, many instruments aimed at assessing such subjective measures have been developed ${ }^{9}$.

Idiopathic scoliosis is a tridimensional deformity that primarily affects females. Previous studies have shown that this condition negatively impacts patients' quality of life ${ }^{10,11}$. Scoliosis was previous related to altered self-image and mental health, and to functional limitations and pain ${ }^{3,6,10-14}$. For these reasons, it is important to measure patients' quality of life.
HRQoL is primarily measured using selfadministered questionnaires. Psychometric properties of these scales, such as score distribution, validity, reliability and sensibility, must be determined ${ }^{15-18}$.

A well-accepted tool in the evaluation of patients' perception of their condition is the Scoliosis Research Society-22 (SRS-22) questionnaire. This questionnaire was developed in English, is specific for patients with idiopathic scoliosis ${ }^{15}$, and has been validated in patients with adult scoliosis, including patients with de novo scoliosis ${ }^{19-21}$. The original SRS HRQoL instrument was developed by Haher et al. ${ }^{22}$ and had 24 questions. Following several modifications to improve its psychometric properties, it became the SRS-22 version ${ }^{1,15}$. This version had acceptable validity, reliability and sensibility values $^{15,23,24}$. However, Asher et al. ${ }^{25}$ demonstrated that the internal consistency of the Function domain decreased when administered to patients under 18 years old. For this reason, the questionnaire was 
altered once more and was renamed the Revised Scoliosis Research Society-22 (SRS-22r). This questionnaire has 22 questions divided into five domains: function/activity, pain, self-image/ appearance, mental health and satisfaction with management. Each domain contains five questions, except the satisfaction with management domain, which contains two questions. Each item can be scored from 1 (worst possible) to 5 (best possible). The function/activity, pain, self-image and mental health domains have a total score ranging from 5 to 25 . The satisfaction with management domain has a total score ranging from 2 to 10 . The maximum total score is 110 and the results are expressed as a mean ${ }^{2,15}$.

With a few exceptions, self-evaluation questionnaires have been developed for use in Englishspeaking countries. In order for the questionnaire to be used in a country with a different culture and language, it is not enough to merely translate it from the original language because the simple translation can alter the conceptual equivalence of the original instrument ${ }^{3,6,16-18,26-29}$. The development of a new version requires transcultural adaptation to account for existing cultural and language differences. Moreover, the conception of quality of life varies among different cultures. Rosanova et al. ${ }^{30}$ verified that the Brazilian version of the SRS-22r questionnaire has satisfactory concurrent validity. This was determined by correlating the Brazilian tool with the Brazilian SF-36 questionnaire. However, the cross-cultural adaptation steps were not described. Additionally, the questionnaire's reliability, which is an important psychometric property, was not reported.

Thus, the aim of this study was to describe the cultural adaptation of the SRS-22r questionnaire for the Brazilian Portuguese language and to determine its reliability. This report will provide more complete information about the questionnaire.

\section{- Method}

Forty-four volunteers, 40 females and 4 males, participated in this study. Participants were recruited by convenience from orthopedic private practices, public orthopedic clinics in the region and the school hospital of the Ribeirão Preto Medical School. Patients were contacted by three of the authors, who also administered the questionnaires. Clinical diagnostics were assessed by orthopedic surgeons. In addition, posterior-anterior standing radiographic images were used to measure each patient's Cobb angle. The mean age of the participants was 18.93 years (ranged from 12 to 36 years) and their average magnitude of scoliosis curve was $54.6^{\circ} \mathrm{Cobb}$ angle (ranged to 10 to $92^{\circ} \mathrm{Cobb}$ angle). Four female patients underwent surgery and reached $20.5^{\circ} \mathrm{Cobb}$ of correction in average. The postoperative curves of these four patients were used in the calculation of the average magnitude of the scoliotic curve. Illiterate patients and patients under 12 years old were excluded due to their limited ability to properly understand or read the questionnaire ${ }^{26}$. Individuals with any other musculoskeletal impairments or neurologic pathologies were excluded.

This study protocol was approved by the Ethics Committee for Research Involving Humans Beings of the Faculdade de Medicina de Ribeirão Preto, Universidade de São Paulo (FMRP-USP), Ribeirão Preto, SP, Brazil (approval number 9853/2005). The volunteers signed an Informed Consent prior to study participation. For those individuals under 18 years old, parents or legal guardians signed this document to consent to participation.

\section{Cultural adaptation}

The SRS-22r questionnaire was subjected to the cultural adaptation process proposed by Beaton et al. ${ }^{26}$ and recommended by the American Academy of Orthopedic Surgeons (AAOS).

Two independent translations, T1 and T2, were initially performed by two native Brazilian bilingual translators. Next, a synthesis of these two translations, the T-12 version, was produced. Afterwards, the synthesis was translated back into the English language independently by two American translators living in Brazil, resulting in the back-translations BT1 and BT2. This process is used to determine if the translated version reflects the original content of the questionnaire. Next, an expert committee composed of two orthopedic physicians, two physical therapists and one English Language teacher (non-native) revised the $\mathrm{T}-12$ version, the back-translations and the original questionnaire. The committee examined the discrepancies with the aim of resolving them through a consensus and producing a pre-final version of the Brazilian questionnaire. The group's decisions were made with the goal of achieving semantic, idiomatic, experimental and conceptual equivalence with the original instrument. Some alterations were needed to adjust the tool to assess Brazilian patients with idiopathic scoliosis.

The pre-final version was administered to 44 volunteers with idiopathic scoliosis. Patients were instructed to not answer questions that they did not understand or questions that did not apply to 
themselves. The expert committee could have been required to meet once more to judge and propose changes for answer items or whole questions that were not answered by more than $15 \%$ of participants (6 or more volunteers). Proposed changes would maintain the original concept and a new pretesting would be repeated until all questions have good level of understanding ${ }^{16}$. The Brazilian Scoliosis Research Society Revised Questionnaire (SRS-22r) can be seen in Appendix 1. The score sheet is presented in Appendix 2.

\section{Data analysis}

Reliability measures included statistics measuring internal consistency and test/retest reproducibility. Internal consistency was assessed with Cronbach's alpha statistic and test/retest reliability was determined using the Intraclass Correlation Coefficient (ICC 2.1).

Floor effects were not seen in any domain of the questionnaire. Ceiling effects were observed in the Pain and Treatment Satisfaction domains.

\section{Results}

\section{Test of the pre-final version}

After administering it to forty-four individuals with idiopathic scoliosis, the questionnaire was analyzed for its level of comprehension. Campos et al. ${ }^{16}$ posit that the misunderstood questions or those that did not apply for more than $15 \%$ of the studied sample should be changed to preserve their cultural equivalence. In this study, a question would be changed if at least 6 participants did not answer it. The pre-final version of the Portuguese SRS-22r did not require alterations because no question was left unanswered by more than $15 \%$ of the participants in the studied sample.

However, during this phase, a deficiency was noted by the interviewer in the Brazilian version of question 11, as follows:
"Which one of the following best describes your pain medication use for back pain?"

None

Non-narcotics weekly or less (e.g.: aspirin, diclofenac, dipyrone)

Non-narcotics daily (e.g.: aspirin, diclofenac, dipyrone)

Narcotics weekly or less (e.g.: amitriptyline)

Others

Medication:

Use (the whole week or less or everyday):

Of the ten volunteers who affirmed consuming medication for back pain, four chose the last answer "others", but the blank space was used to indicate infrequent drug intake, or drug intake only when pain was present. This item, however, holds the lowest score in the question, representing the worst option. The committee assumed that these patients chose this item because they did not understand the previous higher-score items indicating less frequent medication usage. Based on the Spanish version proposed by Bago et al. ${ }^{2}$, the items in this question were changed as follows:

"Which one of the following best describes your pain medication use for back pain?"

None

Non-narcotics weekly or less (e.g.: aspirin, diclofenac, dipyrone or others)

Non-narcotics daily (e.g.: aspirin, diclofenac, dipyrone or others)

Narcotics weekly or less

Narcotics daily

Table 1 presents the average scores for the 44 volunteers for each domain. The minimum and maximum average scores for each domain and the score distributions are also shown.

\section{Reliability}

The test/retest reliability calculation was carried out using data from thirty of the forty-four volunteers

Table 1. Domain descriptions for the SRS-22 questionnaire.

\begin{tabular}{|c|c|c|c|c|c|c|}
\hline Domain & Average & $\begin{array}{l}\text { Standard } \\
\text { Deviation }\end{array}$ & $\begin{array}{l}\text { Minimum } \\
\text { Score }\end{array}$ & $\begin{array}{l}\text { Maximum } \\
\text { Score }\end{array}$ & $\begin{array}{c}\% \\
\text { floor effect }\end{array}$ & $\begin{array}{c}\% \\
\text { ceiling effect }\end{array}$ \\
\hline Function / activity & 4.08 & 0.75 & 1.8 & 5 & 0 & 15.90 \\
\hline Pain & 3.99 & 0.87 & 1.2 & 5 & 0 & 25 \\
\hline Self-image & 3.53 & 0.83 & 1.2 & 5 & 0 & 4.54 \\
\hline Mental health & 3.73 & 0.75 & 1.8 & 5 & 0 & 2.27 \\
\hline $\begin{array}{l}\text { Management } \\
\text { satisfaction }\end{array}$ & 4.28 & 0.83 & 2 & 5 & 0 & 36.36 \\
\hline
\end{tabular}


enrolled in the pre-final test. The ICC (2.1) values are presented in Table 2. All domains had excellent ICC values, above 0.90 .

The internal consistency values are presented in Table 3. The domains Pain (0.80), Self-image (0.82), and Mental Health (0.85) had very good internal consistency. Internal consistency values were good for the Function (0.77) and Management Satisfaction domains (0.70).

Unlike in the original and Spanish versions, question 15 had little influence on the internal consistency values in the Function domain. Without this question, Cronbach's alpha decreases from 0.77 to 0.75 .

\section{Discussion}

The important characteristics of a questionnaire are its score distribution and its psychometric properties, specifically reliability, validity and responsiveness ${ }^{15}$. A previous study published by Rosanova et al..$^{30}$ determined the concurrent validity of the Brazilian version of the SRS-22r questionnaire by correlating it to the Brazilian version of the SF-36 questionnaire. The authors verified that the instrument has satisfactory concurrent validity; therefore, this tool is able to measure what it intends to measure.

Table 2. Intraclass correlation coefficient for test/retest reliability.

\begin{tabular}{lccc}
\hline \multicolumn{1}{c}{ Domain } & ICC & \multicolumn{2}{c}{$(\mathbf{9 5 \% )}$} \\
& & Inferior & Superior \\
Function / Activity & 0.94 & 0.89 & 0.98 \\
Pain & 0.93 & 0.89 & 0.98 \\
Self-image & 0.92 & 0.87 & 0.98 \\
Mental health & 0.92 & 0.87 & 0.98 \\
Management satisfaction & 0.96 & 0.93 & 0.99 \\
\hline
\end{tabular}

Table 3. Internal consistency, represented by Cronbach's alpha values.

\begin{tabular}{lcc}
\hline \multicolumn{1}{c}{ Domain } & $\begin{array}{c}\text { Cronbach's } \\
\text { alpha }\end{array}$ & $\begin{array}{c}\text { Cronbach's } \\
\text { alpha for the } \\
\text { original } \\
\text { SRS-22 }\end{array}$ \\
Function / Activity & 0.77 & 0.86 \\
Pain & 0.80 & 0.92 \\
Self-image & 0.82 & 0.75 \\
Mental health & 0.85 & 0.90 \\
Management satisfaction & 0.70 & 0.88 \\
\hline
\end{tabular}

The current study complements the previous work by Rosanova et al. ${ }^{30}$ with two important additions. One novel addition is the description of the crosscultural adaptation process used to translate the instrument to the Brazilian Portuguese language. This process is important for adjusting the new version to target the local population. Beaton et al. ${ }^{26}$ state that the cultural adaptation process maintains the content validity of the questionnaire, preserving the same concepts across various cultures. For this reason, the Brazilian version of the SRS-22r questionnaire was subjected to the cultural adjustment process proposed by these authors and the steps of this process are presented in this study.

The original version of SRS-22 was culturally adapted to Spanish ${ }^{2,31}$, Turkish ${ }^{32}$, Japanese ${ }^{33}$, Chinese $^{34,35}$, French Canadian ${ }^{36}$, German $^{9}$ and Greek $^{37}$.

No domain in the Portuguese Language (Brazil)adapted questionnaire demonstrated a floor effect, as found to German and Canadian versions. However, previous studies that have produced versions of the SRS-22 questionnaire, including the original version, reported low floor effect values. Such studies enrolled larger samples, resulting in more opportunities for a floor effect to occur.

The Brazilian questionnaire exhibited ceiling effects in the Pain and Management Satisfaction domains. This effect was also noted in the original version and in most of the SRS-22 questionnaires adapted for other countries. The original, Spanish, Turkish and German versions also presented a high percentage of ceiling effects for these domains. This indicates that in such domains there is limited ability to distinguish different levels of scoliosis severity. Significative percentage of the sample showing a ceiling effect in the Pain domain can be explained by the absence of pain in idiopathic scoliosis during adolescence and early adulthood. The high ceiling effect in the Treatment Satisfaction domain may reflect patients' confidence in the recruitment hospital, where most patients in this study are treated ${ }^{9,32,34}$. However, unlike the original version, the Brazilian questionnaire was not administered by the operating orthopedic surgeon, but rather by three physical therapy students who were not involved with patients' treatment. This decreases the potential for response bias in the Treatment Satisfaction domain ${ }^{15}$.

The second important addition that complements the work of Rosanova et al. ${ }^{30}$ is the Brazilian instrument's reliability. Test/retest reliability values were considered excellent. All domains had ICC values above 0.90 , which was also true of the original, Spanish and Chinese versions ${ }^{13,37}$. 
Cronbach's alpha values for all domains are above 0.70 and thus considered satisfactory. However, the original SRS-22 has better internal consistency values. According to Bago et al. ${ }^{2}$, it is typical for culturally adapted questionnaires to have slightly inferior internal consistency than the original tool.

Asher et al. ${ }^{25}$ observed that questions 15 and 18 decreased the internal consistency of the Function domain in the original SRS-22 when applied to individuals younger than 18 years old. A similar phenomenon occurred using the Spanish ${ }^{2}$ and Turkish ${ }^{32}$ versions. Despite this, the authors maintained question 15 unaltered because it assesses the important concept of financial difficulties related to scoliosis, and altered question 18 . Hence, the SRS22 was then named the SRS-22 revised version (SRS22r). In the Brazilian version, question 15 had a slight influence on the internal consistency value of the Function domain. Without this question, Cronbach's alpha decreased from 0.77 to 0.75 . Question 18 was translated and adjusted according to the revised version of the SRS-22r questionnaire during the adaptation process for the Brazilian version.

Question 11 in the Brazilian version decreased the internal consistency of the Pain domain. Cronbach's alpha increased from 0.80 to 0.85 after removing question 11. This is consistent with the observation that some volunteers experienced difficulty with this question during the pre-final test. Of the ten patients who reported medication usage, four answered the question incorrectly. Hence, the authors believe that if most of the volunteers consumed medications for back pain, or if the study sample were larger, there would be more participants with problems with that question. The problems occurred because these items are presented as a consumption frequency scale for medication, increasing from the first to the last item. The last item, "others", receives the worst score. However, three patients chose this item as their answer and reported that they use common medication "sometimes" or "when in pain". This way, they have a lower score than they would have if they were answering the question correctly. As mentioned in the Results section, question 11 has been updated in a similar manner to that recommended by Bago et al. ${ }^{2}$ In the latest validation studies of the English version of the SRS-22r questionnaire ${ }^{25,38}$, question 11 reflects this change. For the sake of completeness it would be desirable to test the Brazilian version once again. However, we believe that published results using the updated question \#11 2,25,38 and our experience detailed here make this unnecessary.
Finally, the questionnaire seemed simple and practical, and its psychometric characteristics were similar to those of the original questionnaire. All questions were answered by more than $15 \%$ of patients. These results suggest that the tool is properly adjusted for use in the population of Brazilian patients with idiopathic scoliosis.

\section{Acknowledgements}

The authors would like to thank Mr. A. Asher, from the Department of Orthopedic Surgery of the Kansas University Medical Center, for his valuable comments during manuscript preparation. The authors also would like to thank the Fundação de Amparo à Pesquisa do Estado de São Paulo - FAPESP (2005/56130-3).

\section{References}

1. Asher MA, Lai SM, Burton DC. Further Development and Validation of the Scoliosis Research Society (SRS) Outcomes Instrument. Spine (Phila Pa 1976). 2000;25:2381-6. PMid:10984792. http://dx.doi. org/10.1097/00007632-200009150-00018

2. Bago J, Climent JM, Ey A, Pere-Grueso FJ, Izquierdo E. The Spanish Version of the SRS-22 Patient Questionnaire for Idiopathic Scoliosis: Transcultural Adaptation and Reliability Analysis. Spine (Phila Pa 1976). 2004;29:167680. PMid:15284516. http://dx.doi.org/10.1097/01. BRS.0000132306.53942.10

3. Danielsson AJ, Wiklund I, Pehrsson K, Nachemson AL. Health-Related Quality of Life in Patients With Adolescent Idiopathic Scoliosis: A Matched Follow-up at Least 20 Years After Treatment With Brace or Surgery. Eur Spine J. 2001;10:278-88. PMid:11563612 PMCid:PMC3611508. http://dx.doi.org/10.1007/s005860100309

4. Feise RJ, Donaldson S, Crowther ER,Menke JM, Wright JG. Construction and Validation of the Scoliosis Quality of Life Index in Adolescent Idiopathic Scoliosis. Spine (Phila Pa 1976). 2005;30:1310-1315. PMid:15928558. http://dx.doi.org/10.1097/01.brs.0000163885.12834.ca

5. Kirkley A, Griffin S. Development of DiseaseSpecific Quality of Life Measurement Tools. Arthroscopy. 2003;19:1121-8. PMid:14673455. http:// dx.doi.org/10.1016/j.arthro.2003.10.028

6. Padua R, Padua S, Aulisa L, Ceccarelli E, Padua L, Romanini E, et al. Patient Outcomes After Harrington Instrumentation for Idiopathic Scoliosis. Spine (Phila Pa 1976). 2001;26:1268-73. PMid:11389396. http://dx.doi. org/10.1097/00007632-200106010-00019

7. Padua R, Padua L, Ceccarelli E, Romanini E, Bondì R, Zanoli G, et al. Cross-Cultural Adaptation of the Lumbar North American Spine Society Questionnaire for ItalianSpeaking Patients With Lumbar Spinal Disease. Spine (Phila Pa 1976). 2001;26:E344-7. PMid:11474366. http:// dx.doi.org/10.1097/00007632-200108010-00012 
8. Dawson J, Carr A. Outcomes Evaluation in Orthopaedics. J Bone Joint Surg Br. 2001;83:313-135. http://dx.doi. org/10.1302/0301-620X.83B3.12148

9. Niemeyer T, Schubert C, Halm HF, Herberts T, Leichtle C, Gesicki M. Validity and Reliability of an Adapted German Version of Scoliosis Research Society-22 Questionnaire. Spine (Phila Pa 1976). 2009;34:818-21. PMid:19365251. http://dx.doi.org/10.1097/BRS.0b013e31819b33be

10. Freidel K, Petermann F, Reichel D, Steiner A, Warschburger P, Weiss HR. Quality of life in Women With Idiopathic Scoliosis. Spine (Phila Pa 1976). 2002;27:E87-E91. PMid:11840115. http://dx.doi. org/10.1097/00007632-200202150-00013

11. Schwab F, Dubey A, Pagala H, Gamez L, Farcy JP. Adult Scoliosis: A Health Assessment Analysis by SF-36. Spine (Phila Pa 1976). 2003;28:602-606. PMid:12642769. http:// dx.doi.org/10.1097/01.BRS.0000049924.94414.BB

12. Goldberg MS, Mayo NE, Poitras B, Scott S, Hanley J. The Ste-Justine Adolescent Idiopathic Scoliosis Cohort Study. Part II: Perception of Health, Self and Body Image, and Participation in Physical Activities. Spine (Phila Pa 1976). 1994;19:1562-72. PMid:7939992. http://dx.doi. org/10.1097/00007632-199407001-00004

13. Parent EC, Hill D, Moreau M, Mahood J, Raso J, Lou E. Score Distribution of the Scoliosis Quality of Life Index Questionnaire in Different Subgroups of Patients With Adolescent Idiopathic Scoliosis. Spine (Phila Pa 1976). 2007;32:1767-77. PMid:17632398. http://dx.doi. org/10.1097/BRS.0b013e3180b9f7a5

14. Payne WK 3rd, Ogilvie JW, Resnick MD, Kane RL, Transfeldt EE, Blum RW. Does Scoliosis Have a Psychological Impact and Does Gender Make a Difference? Spine (Phila Pa 1976). 1997;22:1380-1384. PMid:9201842. http://dx.doi.org/10.1097/00007632-199706150-00017

15. Asher MA, Lai SM, Burton D, Manna B. The Reliability and Concurrent Validity of the Scoliosis Research Society-22 Patient Questionnaire for Idiopathic Scoliosis. Spine (Phila Pa 1976). 2003;28:63-9. PMid:12544958. http://dx.doi.org/10.1097/00007632-200301010-00015

16. Campos CC, Manzano GM, Andrade LB, Castelo A F ${ }^{\circ}$, Nóbrega JAM. Tradução e Validação do Questionário de Avaliação de Gravidade dos Sintomas e do Estado Funcional na Síndrome do Túnel do Carpo. Arq Neuropsiquiatr. 2003;61:51-55. PMid:12715019. http:// dx.doi.org/10.1590/S0004-282X2003000100009

17. Ciconelli RM, Ferraz MB, Santos W, Meinão I, Quaresma MR. Tradução para a língua portuguesa e validação do questionário genérico de avaliação de qualidade de vida SF-36 (Brasil SF-36). Rev Bras Reumatol. 1999;39:143-50.

18. Padua R, Padua L, Ceccarelli E, Romanini E, Zanoli G, Bondì R, et al. Italian Version of the Roland Disability Questionnaire, specific for low back pain: cross-cultural adaptation and validation. Eur Spine J. 2002;11:126-9. PMid:11956918 PMCid:PMC3610499. http://dx.doi. org/10.1007/s005860100262

19. Baldus C, Bridwell KH, Harrast J, Edwards C 2nd, Glassman S, Horton W, et al. Age-Gender Matched Comparison of SRS Instrument Scores Between Adult Deformity and Normal Adults. Are all SRS Domains
Desease Specific? Spine (Phila Pa 1976). 2008;33:22148. PMid:18794764. http://dx.doi.org/10.1097/ BRS.0b013e31817c0466

20. Bridwell KH, Berven S, Glassman S, Hamill C, Horton WC 3rd, Lenke LG, et al. Is the SRS-22 Instrument Responsive to Change in Adult Scoliosis Patients Having Primary Spinal Deformity Surgery? Spine (Phila Pa 1976). 2007;32:2220-5. PMid:17873814. http://dx.doi. org/10.1097/BRS.0b013e31814cf120

21. Bridwell KH, Cats-Baril W, Harrast J, Berven S, Glassman S, Farcy JP, et al. The Validity of the SRS-22 Instrument in an Adult Spinal Deformity Population Compared With the Oswestry and SF-12. Spine (Phila Pa 1976). 2005;30:45561. PMid:15706344. http://dx.doi.org/10.1097/01. brs.0000153393.82368.6b

22. Haher TR, Gorup JM, Shin TM, Homel P, Merola AA, Grogan DP, et al. Results of the Scoliosis Research Society Instrument for Evaluation of Surgical Outcome in Adolescent Idiopathic Scoliosis. A Multicenter Study of 224 Patients. Spine (Phila Pa 1976). 1999;24:1435-40. PMid:10423788. http://dx.doi. org/10.1097/00007632-199907150-00008

23. Asher MA, Lai SM, Burton D, Manna B. Scoliosis Research Society-22 Patient Questionnaire: Responsiveness to Change Associated With Surgical Treatment. Spine (Phila Pa 1976). 2003;28:70-3. PMid:12544959. http://dx.doi. org/10.1097/00007632-200301010-00016

24. Asher MA, Lai SM, Burton D, Manna B. Discrimination Validity of the Scoliosis Research Society-22 Patient Questionnaire. Spine (Phila Pa 1976). 2003;28:74-78. PMid:12544960. http://dx.doi. org/10.1097/00007632-200301010-00017

25. Asher MA, Lai SM, Glattes RC, Burton DC, Alanay A, Bago J. Refinement of the SRS-22 Health-Related Quality of Life Questionnaire Function Domain. Spine (Phila Pa 1976). 2006;31:593-7. PMid:16508558. http://dx.doi. org/10.1097/01.brs.0000201331.50597.ea

26. Beaton DE, Bombardier C, Guillemin F, Ferraz MB. Guidelines for the Process of Cross-Cultural Adaptation of Self-Report Measures. Spine (Phila Pa 1976). 2000;25:3186-91. PMid:11124735. http://dx.doi. org/10.1097/00007632-200012150-00014

27. Bullinger M, Alonso J, Apolone G, Leplège A, Sullivan M, Wood-Dauphinee S, et al. Translating Health Status Questionnaires and Evaluating Their Quality: The IQOLA Project Approach. J Clin Epidemiol. 1998;51:913-23. http://dx.doi.org/10.1016/S0895-4356(98)00082-1

28. Chaory K, Fayad F, Rannou F, Lefèvre-Colau MM, Fermanian J, Revel M, et al. Validation of the French version of the fear avoidance belief questionnaire. Spine (Phila Pa 1976). 2004;29:908-13. PMid:15082995. http:// dx.doi.org/10.1097/00007632-200404150-00018

29. Guillemin F, Bombardier C, Beaton D. Cross-Cultural Adaptation of Health-Related Quality of Measures: Literature Review and Proposed Guidelines. J Clin Epidemiol. 1993;46:1417-1432. http://dx.doi. org/10.1016/0895-4356(93)90142-N

30. Rosanova GC, Gabriel BS, Camarini PM, Gianini PE, Coelho DM, Oliveira AS. Concurrent Validity of the Brazilian Version of SRS-22r with Br-Sf-36. Rev Bras 
Fisioter. 2010;14(2):121-6. PMid:20464160. http://dx.doi. org/10.1590/S1413-35552010005000012

31. Climent JM, Bago J, Ey A, Perez-Grueso FJ, Izquierdo E. Validity of the Spanish Version of the Scoliosis Research Society-22 (SRS-22) Patient Questionnaire. Spine (Phila Pa 1976). 2005;30:705-709. PMid:15770189. http:// dx.doi.org/10.1097/01.brs.0000155408.76606.8f

32. Alanay A, Cil A, Berk H, Acaroglu RE, Yazici M, Akcali $\mathrm{O}$, et al. Reliability and Validity of Adapted Turkish Version of Scoliosis Research Society-22 (SRS-22) Questionnaire. Spine (Phila Pa 1976). 2005;30:24648. PMid:16261127. http://dx.doi.org/10.1097/01. brs.0000184366.71761.84

33. Hashimoto H, Sase T, Arai Y, Maruyama T, Isobe K, Shouno Y. Validation of a Japanese Version of the Scoliosis Research Society-22 Patient Questionnaire Among Idiopathic Scoliosis Patient in Japan. Spine (Phila Pa 1976). 2007;32:E141-6. PMid:17304124. http://dx.doi. org/10.1097/01.brs.0000255220.47077.33

34. Cheung KC, Senkoylu A, Alanay A, Genc Y, Lau S, Luk KD. Reliability and Concurrent Validity of the Adapted Chinese Version of Scoliosis Research Society-22 (SRS22) Questionnaire. Spine (Phila Pa 1976). 2007;32:11415. PMid:17471100. http://dx.doi.org/10.1097/01. brs.0000261562.48888.e3

35. Zhao L, Zhang Y, Sun X, Du Q, Shang L. The Scoliosis Research Society-22 Questionnaire Adapted for Adolescent Idiopathic Scoliosis in China: Reliability and Validity Analysis. J Child Orthop. 2007;1:351-355. PMid:19308531 PMCid:PMC2656752. http://dx.doi. org/10.1007/s11832-007-0061-1
36. Beauséjour M, Joncas J, Goulet L, Roy-Beaudry M, Parent S, Grimard G, et al. Reliability and Validity of Adapted French Canadian Version of Scoliosis Research Society Outcomes Questionnaire (SRS-22) in Quebec. Spine (Phila Pa 1976). 2009;34:623-8. PMid:19282743. http:// dx.doi.org/10.1097/BRS.0b013e3181973e58

37. Antonarakos PD, Katranitsa L, Angelis L, Paganas A, Koen EM, Christodoulou EA, et al. Reliability and Valididy of the Adapted Greek Version of Scoliosis Research Society-22 (SRS-22) Questionnaire. Scoliosis. 2009;4:17. PMid:19607720 PMCid:PMC2720382. http://dx.doi. org/10.1186/1748-7161-4-14

38. Glattes RC, Burton DC, Lai SM, Frasier E, Asher MA. The Reliability and Concurrent Validity of the Scoliosis Research Society-22 Patient Questionnaire Compared With the Child Health Questionnaire-CF87 Patient Questionnaire for Adolescent Spinal Deformity. Spine (Phila Pa 1976). 2007;16:1778-84. PMid:17632399. http:// dx.doi.org/10.1097/BRS.0b013e3180dc9bb2

\section{Correspondence:}

\section{Paula Maria Ferreira Camarini}

Rua Conselheiro Saraiva, 95, Centro CEP: 13480-190, Limeira, SP, Brasil e-mail: paula_camarini@yahoo.com.br 
Appendix A

\section{Questionário do Paciente SRS-22}

Nome do paciente:

Data do exame:

Registro médico:

Data de nascimento:

Idade:

INSTRUÇÕES: Estamos avaliando cuidadosamente as condições de sua coluna e é IMPORTANTE QUE VOCÊ RESPONDA CADA UMA DESSAS PERGUNTAS SOZINHO. Por favor, FAÇA UM CÍRCULO AO REDOR DA MEHOR RESPOSTA PARA CADA PERGUNTA.

1. Nos últimos 6 meses, qual palavra descreve a intensidade da sua dor?

Nenhuma

Fraca

Moderada

Moderada a forte

Forte

2. No mês passado, qual palavra descreve a intensidade da sua dor?

Nenhuma

Fraca

Moderada

Moderada a forte

Forte

3. Nos últimos 6 meses você tem sido uma pessoa muito ansiosa?

Em nenhum momento

Em poucos momentos

Alguns momentos

Na maior parte do tempo

Em todo o tempo

4. Se você tivesse que passar o resto da sua vida com a forma de sua coluna exatamente como é agora, como você se sentiria?

Muito feliz

Um pouco feliz

Nem feliz nem triste

Um pouco triste

Muito triste

5. Qual é o seu nível atual de atividade?

De cama

Sem praticar nenhuma atividade quase todo tempo

Trabalho leve e esportes leves

Trabalho moderado e esportes moderados

Todas as atividades completas sem restrições 
6. Como é sua aparência usando roupas?

Muito boa

Boa

Regular

Ruim

Muito ruim

7. Nos últimos 6 meses você tem se sentido tão para baixo que nada poderia animá-lo(a)? Sempre

Muitas vezes

Algumas vezes

Raramente

Nunca

8. Você sente dor na coluna quando está repousando?

Sempre

Muitas vezes

Algumas vezes

Raramente

Nunca

9. Sua condição na coluna afeta suas atividades no trabalho/escola?

Não afeta

Afeta pouco

Afeta mais ou menos

Afeta muito

Afeta totalmente

10. O que você acha da aparência da sua coluna hoje?

Muito boa

Boa

Regular

Ruim

Muito ruim

11. Como é o uso de remédios para sua dor na coluna?

Não uso

Toda semana ou menos usando remédio (por exemplo, aspirina, diclofenaco, dipirona)

Todos os dias usando remédios (por exemplo, aspirina, diclofenaco, dipirona)

Toda semana ou menos usando remédios controlados/tarja preta (por exemplo, amitriptilina)

Outros: I

Medicamento

Frequência 
12. Sua coluna limita sua capacidade de fazer trabalhos domésticos?

Nunca

Raramente

Algumas vezes

Muitas vezes

Sempre

13. Você tem se sentido calmo, tranqüilo nos últimos 6 meses?

Em todo tempo

Na maior parte do tempo

Alguns momentos

Em poucos momentos

Em nenhum momento

14. Você acha que a sua coluna interfere na sua vida pessoal?

De forma alguma

Muito pouco

Pouco

Mais ou menos

Muito

15. O problema da sua coluna está causando dificuldades financeiras para você e sua família?

Muito

Mais ou menos

Pouco

Muito pouco

De forma alguma

16. Nos últimos 6 meses você tem se sentido para baixo e triste?

Nunca

Raramente

Algumas vezes

Muitas vezes

Sempre

17. Nos últimos 3 meses você faltou ao trabalho/escola por causa das dores na coluna? Quantas vezes? 0 1

2

3

4 ou mais 
18. A condição de sua coluna limita que você saia com seus amigos/família?

Nunca

Raramente

Algumas vezes

Muitas vezes

Sempre

19. Mesmo com a aparência atual de sua coluna, você se sente atraente?

Sim, muito

Sim, um pouco

Nem atraente, nem não atraente

Não, não muito

Não, nem um pouco

20. Você tem sido uma pessoa feliz nos últimos 6 meses?

Em nenhum momento

Em poucos momentos

Alguns momentos

Na maior parte do tempo

Em todo o tempo

21. Você está satisfeito(a) com os resultados do tratamento da sua coluna?

Muito satisfeito(a)

Satisfeito(a)

Nem satisfeito(a) e nem insatisfeito(a)

Insatisfeito(a)

Muito insatisfeito(a)

22. Você faria o mesmo tratamento outra vez se você tivesse o mesmo problema?

Sim, com certeza

Talvez sim

Não tenho certeza

Talvez não

Com certeza, não

Obrigado por responder esse questionário. Por favor, fique à vontade para fazer qualquer comentário. 
Appendix B

\section{Questionário Br-SRS-22r: Folha de Pontuação}

Nome:

\begin{tabular}{|c|c|c|c|c|}
\hline DOMÍNIO & $\begin{array}{c}\text { Pontuação: } \\
5 \text { melhor } \\
1 \text { pior }\end{array}$ & $\begin{array}{l}\text { Pontuação total (possível) } \\
\text { A }\end{array}$ & $\begin{array}{c}\text { Questões respondidas } \\
\text { B }\end{array}$ & $\begin{array}{c}\text { Pontuação média } \\
\text { A/B }\end{array}$ \\
\hline \multirow[t]{5}{*}{ Função/atividade } & $5 *$ & & & \\
\hline & 9 & & & \\
\hline & 12 & $(25)$ & $(5)$ & \\
\hline & 15 & & & \\
\hline & 18 & & & \\
\hline \multirow[t]{5}{*}{ Dor } & 1 & & & \\
\hline & 2 & & & \\
\hline & 8 & $(25)$ & 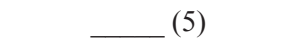 & \\
\hline & 11 & & & \\
\hline & 17 & & & \\
\hline \multirow[t]{5}{*}{ Auto-imagem/aparência } & 4 & & & \\
\hline & 6 & & & \\
\hline & 10 & $(25)$ & $(5)$ & \\
\hline & 14 & & & \\
\hline & 19 & & & \\
\hline \multirow[t]{6}{*}{ Saúde mental } & 3 & & & \\
\hline & 7 & & & \\
\hline & 13 & (25) & $(5)$ & 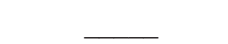 \\
\hline & 16 & & & \\
\hline & 20 & & & \\
\hline & SUBTOTAL & 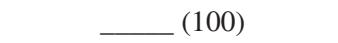 & (20) & 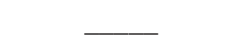 \\
\hline \multirow[t]{3}{*}{ Satisfação com tratamento } & 21 & 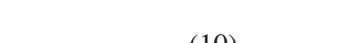 & & \\
\hline & 22 & {$[(10)$} & $-(2)$ & \\
\hline & TOTAL & $(110)$ & (22) & 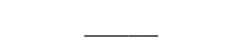 \\
\hline
\end{tabular}

*Número da questão **escore médio: 5 melhor-1pior

\section{INSTRUÇÕES PARA PONTUAÇÃO:}

Questões não respondidas: reduzir o denominador das questões respondidas pelo número apropriado

Deletar questões com mais de uma resposta

Não se pode pontuar domínio se menos que 3 questões forem respondidas 